\title{
Innovative Thinking of Enterprise Human Resources Management Under the New Situation
}

Hua Zheng

HaoJing College of Shaanxi University of Science \& Technology, Xianyang 712046, Shaanxi, China. E-mail: 13201666233@163.com

Abstract: Human resource management is an important part of enterprise management, and its management quality is related to the development of enterprises. Under the new situation, market competition is becoming increasingly fierce. If companies want to occupy a favorable position in the fierce market competition, they need to innovate human resource management ideas. Based on this, this article starts with the opportunities and challenges faced by enterprise human resource management under the new situation, and proposes new ideas for innovative human resource management for reference.

Keywords: New Situation; Human Resources; Management; Innovative Ideas

The development of an enterprise is inseparable from high-quality talents, and strengthening the management of highquality talents can substitute for the efficiency of enterprise management and promote the improvement of the overall economic benefits of the enterprise. Therefore, the implementation of corporate human resource management is an important factor in enhancing corporate competitiveness. Nowadays, many enterprises in our country are not efficient in human resource management, and the overall profitability of the enterprise is not good. Therefore, it is necessary to innovate human resource management ideas, fully utilize the advantages of talents, and promote the sustainable and healthy development of enterprises.

\section{Opportunities and challenges faced by enterprise human resource management under the new situation}

With the continuous development and progress of society, the influx and integration of network informatization and digitization have caused great changes in the traditional industry structure. Many emerging industries based on digital and information have emerged, making the human resource management of enterprises face With new opportunities and challenges. Enterprises are an important pillar to promote the emergency development of the country, and labor is an important resource for the sustainable development of enterprises. Whether the human resources of Chinese enterprises can meet the requirements of the new economic environment and new changes have occurred, so that enterprises can occupy in the fierce market competition one of the main factors of dominance ${ }^{[1]}$.

Under the new situation, strengthening corporate human resource management is the key content of corporate management. Only strengthening human resource management can promote the sustainable development of enterprises. In human resource management, enterprises need to formulate effective training programs and institutional systems based on actual conditions. In addition, business management personnel also need to keep up with the pace of development of the times, scientifically plan and manage talents, so that each staff member can give full play to their advantages in corresponding jobs. If the enterprise has the problem of unscientific human resource management, it will have a great impact on the development of

Copyright(C) 2020 Hua Zheng

doi: 10.18686/ahe.v4i10.2953

This is an open-access article distributed under the terms of the Creative Commons Attribution Non-Commercial License (http://creativecommons. org/licenses/by-nc/4.0/), which permits unrestricted non-commercial use, distribution, and reproduction in any medium, provided the original work is properly cited. 
the enterprise. Therefore, under the background of the new era, companies must accurately grasp market development trends, update their own management ideas and methods in a timely manner, combine excellent human resource management methods at home and abroad, innovate their own management methods, and promote the development of the enterprise economy ${ }^{[2]}$.

\section{Innovative ideas for enterprise human resource management under the new situation}

\subsection{Update management concepts and break through the shackles of traditional thinking}

First, the human resource management department needs to get out of the shackles of traditional thinking mode, put human resource management in an important position of strategic development, as a key task, and continuously improve the management ability and level of human resource management staff.

Second, break the routine, tap and train outstanding talents. First of all, it is necessary to divide the talents. You cannot simply think that the higher the position is the talents. It is necessary to explore talents from multiple angles, and increase the training of innovative talents. Second, the evaluation of talents cannot be just Pay attention to academic qualifications and positions, but also need to combine practical experience, and their job competencies, accomplishments, etc.; finally, the introduction of talents should not only be introduced from outside, but also excavated and cultivated from within the enterprise ${ }^{[3]}$.

Third, establish a people-oriented management idea. To do a good job in human resources management, it is necessary to adhere to the people-oriented concept, respect the dominant position of people, mobilize the enthusiasm and enthusiasm of each staff member, and let them better serve the development of the enterprise. Only by respecting each employee, recognizing each employee, thinking more about employees, focusing on employees, and developing human resources management around them, can companies better achieve corporate development goals and talent training goals ${ }^{[4]}$.

\subsection{Create a characteristic modern enterprise innovation culture and create a learning enterprise}

First, the establishment of a characteristic corporate culture. To create a distinctive corporate culture, it is necessary to absorb the valuable parts of traditional culture and use advanced management concepts to do a good job in corporate management. If a good corporate culture is formed, and the corporate system within the culture, the norms will no longer be restricted, and it will become a conscious behavior of the staff. A healthy corporate culture can better guide and standardize the work behavior of the staff, guide them to work in strict accordance with the requirements, and make the staff feel satisfied and more consciously engaged in work.

Second, the concept of corporate talent is part of corporate culture. The enterprise creates a good cultural atmosphere, there are new thinking and new paths that can mobilize employees to develop innovatively, and it will mobilize employees to continuously reflect on their own work behavior, develop their innovative thinking, and attract more outstanding talents.

Third, there is consistency between an innovative culture and a learning enterprise. The management model and concept of a learning enterprise, the good atmosphere created by the enterprise, and the enterprise development model are all manifestations of the corporate culture and the key to the healthy development of the enterprise. This can not only improve the quality and efficiency of work, but also attract the attention of employees, so that they will be affected by the good cultural atmosphere of the company and will not "displace" outside the company. After learning management, an enterprise can be cultivated into a learning enterprise, which is the guarantee of enterprise innovation and development.

\subsection{Implement flexible management and update incentive measures}

First, flexibility means to improve the cultural literacy of corporate staff, reduce the distance between managers and managers, and the relationship between the company and employees has changed from the traditional "contract" relationship to the "covenant" relationship. The management model is developing towards flexible management. Flexible management no longer relies solely on planning organizational structure and system management, but a new management model with strong flexibility. In the process of enterprise human resource management, flexible management mainly embodies the characteristics of flexibility such as "harmony" and "flexibility". It is a method adopted under the condition of respecting personal development and enhancing the cohesion of staff to the enterprise. This kind of management method can be applied to enterprise human resource management work, which can greatly improve the quality and efficiency of management work ${ }^{[5]}$.

Second, the implementation of flexible management requires innovation in working mechanisms. Human resource 
management must strengthen the system construction and carry out refined management. This requires human resource management through scientific management and spiritual interaction with employees, and flexible management to create a relaxed and harmonious atmosphere for employees. They have more rights and benefits in order to mobilize their creative desires and make their potentials effective. The application of incentives can promote the realization of corporate management goals, etc., so that employees can feel that they are recognized and respected by the company, so that they can find the meaning and value of their work and complete their work more consciously.

\subsection{Emphasize management innovation}

To innovate in human resource management, we need to start from the following aspects: First, transform the functions of the human resource management department. This is because the organization and management model of the enterprise has changed with the change of the market environment. By changing the management function and making the management function hierarchical, the management of the enterprise can be optimized, and people can also use more autonomy and more effective. Implement human resource management.

Second, divide the functions of human resource management scientifically. Human resource management functions include various aspects such as the selection and recruitment of talents, and various functions influence and interact with each other. Due to changes in the external environment, these functions must be divided to achieve the best management effect and reduce cost input.

Third, the institutionalization and systemization of human resource management. Human resource management needs to be strengthened in terms of institutionalization and systemization, highlight the role and cohesion of human resources, strengthen the sense of mission and responsibility of the staff, and work hard to achieve the goals of enterprise development. In addition, it is necessary to build a sound profit-driven system that varies from person to person and integrates with the performance and salary of the staff.

\section{Conclusion}

All in all, human resource management is a harmonious part of corporate management and the key to enhancing corporate competitiveness. Therefore, in the daily management of enterprises, we must pay attention to human resource management, constantly update human resource management thoughts and methods, create a characteristic modern corporate innovation culture, create a learning enterprise, emphasize management innovation, and strengthen the system The construction of the company will give full play to the advantages and functions of human resource management and promote the sustainable and healthy development of the enterprise.

\section{References}

1. Zhou BY, Guo PL, et al. Innovative ideas and countermeasures of enterprise human resource management under the new situation-taking hotels as an example. Jiangsu Business Forum 2018; 2(13): 129-136.

2. Shen HX. Analysis of the problems and countermeasures in the human resource management of small and medium-sized enterprises in my country under the new situation. Zhifu Times 2018; 10(22): 329-346.

3. Zhang $\mathrm{X}$, et al. On the reform and innovation of enterprise human resource management under the new situation.shangqing 2018; 6(08): 429-621.

4. Zhou D, Ding XY. Discussion on the innovation path of strengthening enterprise human resource management under the new situation. Enterprise Reform and Management, 2017; 6(22): 529-631.

5. Xi X, Zhang SY. Analysis of the innovation trend of enterprise human resource management under the new situation. Industry and Technology Forum, 2018; 3(21): 329-421. 